\title{
Stearoyl-Coenzyme A Desaturase Gene Polymorphism and Milk Fatty Acid Composition in Italian Holsteins
}

\author{
M. Mele,${ }^{\star 1}$ G. Conte, ${ }^{*}$ B. Castiglioni, $†$ S. Chessa, $\ddagger$ N. P. P. Macciotta,§ A. Serra, ${ }^{\star}$ A. Buccioni,\# \\ G. Pagnacco, $¥$ and P. Secchiari* \\ *Dipartimento di Agronomia e Gestione dell'Agroecosistema, University of Pisa, Italy \\ †Istituto di Biologia e Biotecnologia Agraria, CNR, Milan, Italy \\ ‡Dipartimento di Scienze e Tecnologie Veterinarie per la Sicurezza Alimentare-University of Milan, Italy \\ §Dipartimento di Scienze Zootecniche, University of Sassari, Sassari, Italy \\ \#Dipartimento di Scienze Zootecniche, University of Florence, Florence, Italy
}

\begin{abstract}
Milk fatty acid composition is a parameter of great interest for evaluation of nutritional quality of milk. Stearoyl-CoA desaturase (SCD) is a key enzyme in mammary lipid metabolism because it is able to add a double bond in the cis $\Delta^{9}$-position in a large spectrum of medium- and long-chain fatty acids. A polymorphism with 2 alleles (A and V) in the fifth exon of the $S C D$ gene has been reported. The effect of $S C D$ genotype on individual milk fatty acid composition and on cis-9 unsaturated/saturated fatty acid ratios of 297 Holstein Italian Friesian cows was investigated in this paper. The $S C D$ genotypes were determined by using a single strand conformation polymorphism method. Relative frequencies of $S C D$ genotypes were 27,60 , and $13 \%$ for AA, AV, and VV, respectively. Milk of AA cows had a greater content of cis-9 C18:1 and total monounsaturated fatty acids and a higher $\mathrm{C} 14: 1 / \mathrm{C} 14$ ratio than did milk of VV cows. The relative contribution of $S C D$ genotype to variation of monounsaturated fatty acids, cis-9 C18:1, and cis-9 C14:1 was 5, 4, and 7.7\%, respectively. No significant differences were detected between $S C D$ genotypes in the milk content of cis-9, trans-11 C18:2. Results of the present work provide some indication of an association between $S C D$ locus and the fatty acid profile in the examined sample of Italian Holsteins, thus suggesting a possible role of this gene in the genetic variation of milk nutritional properties.
\end{abstract}

Key words: stearoyl-CoA desaturase polymorphism, conjugated linoleic acid, monounsaturated fatty acid

\section{INTRODUCTION}

The fatty acid (FA) fraction of ruminant's milk contains several compounds of great interest for human

Received September 21, 2006.

Accepted May 15, 2007.

${ }^{1}$ Corresponding author: mmele@agr.unipi.it health, such as monounsaturated FA (mainly oleic acid) and conjugated linoleic acids (CLA). Studies aimed at finding efficient strategies to improve the nutritional quality of milk concluded that feeding supplementation is the most efficient way to modify milk FA (Palmquist et al., 1993; Jenkins and McGuire, 2006), even if a recent study suggested that the genetic improvement of the nutritional quality of milk based on FA profile may be possible (Soyeurt et al., 2006). However, traditional selection programs based on performance recording and prediction of breeding values could be constrained by the high costs for the measurement of phenotypes. The search for loci affecting FA profiles and their use in marker assisted selection programs offer an alternative to modify nutritional qualities of milk through genetic selection.

Among the several enzymes known to affect the lipid metabolism of the mammary gland, the stearoyl-CoA desaturase enzyme (SCD; also known as $\Delta^{9}$-desaturase) plays a key role because it introduces a double bond at the $\Delta^{9}$-position in a large spectrum of FA (Ntambi, 1999; Ntambi and Miyazaki, 2004). Its most important substrates are acyl-CoA of C14, C16, C18, and trans-11 C18:1 (known as vaccenic acid), which are converted into C14:1 n-5, C16:1 n-7, cis-9 C18:1, and cis-9, trans-11 C18:2, respectively (Corl et al., 2001), the latter being a CLA isomer of great interest due to its antiatherogenic, anticarcinogenic, and immunomodulating properties (Pariza, 1999). More than $70 \%$ of the cis-9, trans-11 CLA of ruminant's milk is produced in the mammary tissue by the activity of SCD (Bauman et al., 2006).

The $S C D$ locus has been mapped on the bovine chromosome 26 . It is $17,088 \mathrm{bp}$ long with an open reading frame of 1,080 bp and codes for 359 amino acids. Three single nucleotide polymorphisms (SNP) in complete linkage disequilibrium and that result in 2 haplotypes have been detected in the fifth exon (Taniguchi et al., 2004). The third SNP causes the substitution of valine 


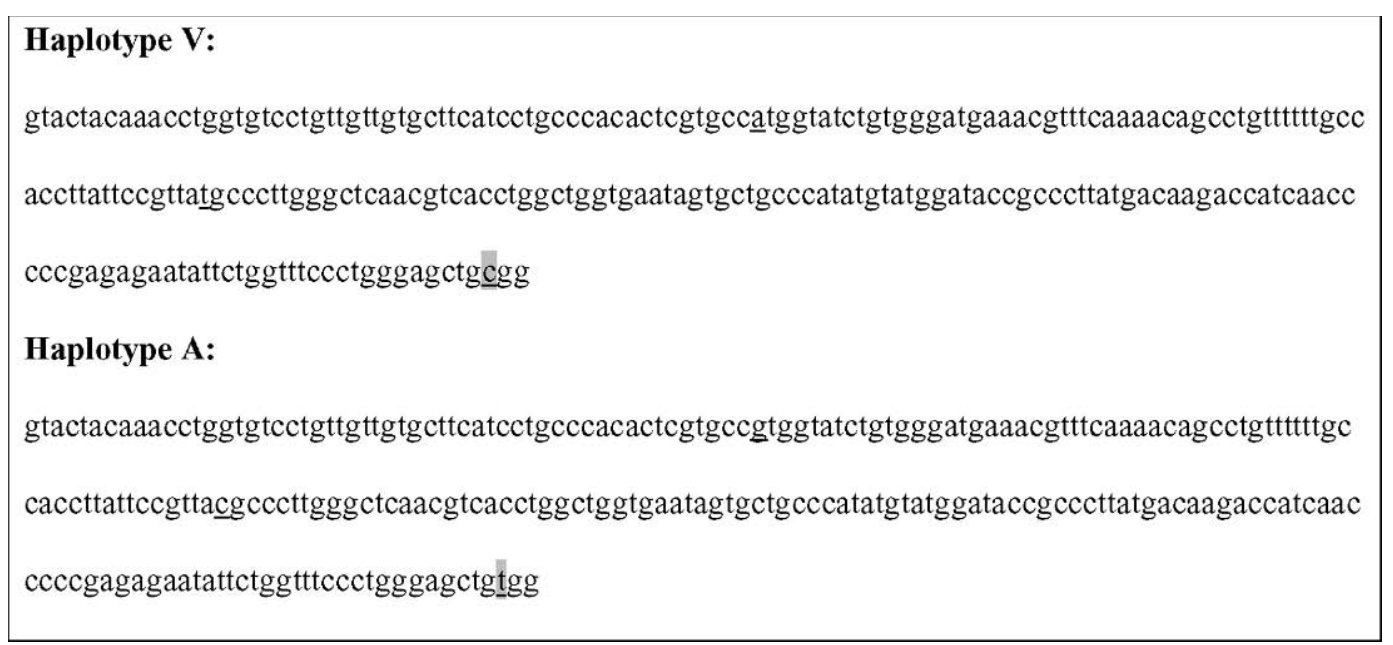

Figure 1. Bovine stearoyl-CoA desaturase $(S C D)$ polymorphism. The gray boxes show the nucleotide substitution that causes the amino acid replacement valine $293 \rightarrow$ alanine 293 .

(allele V) with alanine (allele A) on the 293rd residue (Figure 1). Because valine is highly conserved across mammals, it is considered the ancestral amino acid in that position (Taniguchi et al., 2004). The $S C D$ polymorphism has been found in Holstein Friesian, Jersey, Brown Swiss, and Japanese Black cattle breeds (Medrano et al., 1999; Taniguchi et al., 2004).

On the basis of the $S C D$ gene function and of the relationships between its genetic polymorphism and FA composition of carcass fat recently observed in cattle (Taniguchi et al., 2004), this locus may be a possible candidate gene able to explain a portion of the genetic variability of milk FA content in cows. The objective of this study was the investigation of possible associations between $S C D$ polymorphisms and milk FA composition in Italian Holsteins.

\section{MATERIALS AND METHODS}

\section{Animals}

The analysis was carried out on 297 Italian Holstein Friesian cows sampled from 21 half-sib families (14 \pm 2 daughters per bull) and distributed in 34 herds ( $9 \pm$ 3 cows per herd) located in the northeast of Italy.

\section{DNA Extraction and Amplification}

Genomic DNA was extracted from milk somatic cells with the GFX Genomic Blood DNA Purification Kit (Amersham Biosciences, Uppsala, Sweden) following the supplier's protocol with some modifications. Briefly, $900 \mu \mathrm{L}$ of RBC lysis solution were added to $300 \mu \mathrm{L}$ of milk in a $1.5-\mathrm{mL}$ microcentrifuge tube, incubated at room temperature, and then centrifuged at $11,300 \times g$ for $1 \mathrm{~min}$. The supernatant was removed, and the residual fluid was vortexed and then mixed with $500 \mu \mathrm{L}$ of extraction solution and incubated at room temperature. The mixture was then transferred to the GFX column and centrifuged at $4,300 \times g$ for 2 min. The DNA was removed with an extraction solution (buffered solution containing chaotrope and detergent) and centrifuged again at $4,300 \times g$ for $2 \mathrm{~min}$. A second washing with $500 \mu \mathrm{L}$ of wash solution (Tris-EDTA buffer added with absolute ethanol) was performed, followed by a full speed centrifuge $(11,300 \times g)$ for $4 \mathrm{~min}$. The GFX column was transferred into a fresh $1.5-\mathrm{mL}$ tube for the elution. One hundred microliters of $70^{\circ} \mathrm{C}$ preheated double-distilled water were added directly to the fiberglass matrix of the column. After 1 min of incubation at room temperature, the tube was centrifuged at 4,300 $\times g$ for $2 \mathrm{~min}$ to collect the purified DNA.

The fifth exon region of the $S C D$ gene was amplified by PCR (GeneAmp PCR 9600; Perkin Elmer Life Sciences). Specific primers were designed on the basis of the bovine $S C D$ gene sequence (Medrano et al., 2003, accession no. AY241932) at GenBank (Figure 2):

\section{SCD-9848F: 5'-CAGTCCTTGCTCCACCACTT-3'; SCD-10572R: 5'-AGCATTTGTGGCTTGCTCTT-3'; \\ SCD-9961F: 5'-CCCATTCGCTCTTGTTCTGT-3'; \\ $S C D$-10355R: 5'-GTCTTGCTGTGGACTGCTGA-3'.}

The DNA was preheated at $94^{\circ} \mathrm{C}$ for 5 min and then amplified with 30 cycles of $94^{\circ} \mathrm{C}$ for $45 \mathrm{~s}, 56^{\circ} \mathrm{C}$ for 45 $\mathrm{s}$, and $72^{\circ} \mathrm{C}$ for $1 \mathrm{~min}$. The final cycle had an extension time of $7 \mathrm{~min}$ at $72^{\circ} \mathrm{C}$. The PCR reaction was performed using a mix of $12.5 \mu \mathrm{L}$ of $2 \times$ PCR Master Mix (Fer- 
9721 gaaaggaagcccaaaggcagaa cagaaa aacccgggaaggagaact cag tctgtaatt tg

9781 gacc ctgtctatttccctgaagtagtaaaagagagcaatggatttagagtcaggagatga

SCDD-9848F

9841 acattccagtccttgctccaccacttcctggtagtgtgaccctagaaagtcatttaac

9901 ccctcat tacctcatctcagaagtatgataa taacactgtattctcagaaaatttcct tg

\title{
SCD-9961F
}

9961 cccattcgct cttgttctgttgcctgccacactgtgctet cag tgt agaaaggga cagcc

10021 ccgccctgtgagagtggaaaat caggtaggt ctcagcgtcccctct ccactcact gag cc

10081 tgtgatctct caatgcagg tac tacaaacctggtgtcctgttgttg tgcttcatcctgcc

10141 cacactcgtgccatgg tatctg tgggatgaaacg tttcaaaacagc ctg ttttttgccac

10201 cttattccgt tatgcc cttgggetcaacgtcacc tggetggtgaatagtgctgcc catat

10261 g tatgga tac cgecet tatgac aagacc atc aacccc cgagagaatattctggtt tcc ct

\begin{abstract}
SCD-10355R
10321 gggagctgcgggt aagtcagcagtccacagcaagaccacg tctagtggt ctgetgcttag

10381 ggtattaggt tacgtgccagaa aaactagatttacctgtt ttatgaccctctccatatg

10441 tcattccact ataaaactaagggacagt att agaaaacccttgaaagttaagcaa caagt
\end{abstract}

10501 cctatgtaaagagaaaagggtgaaaatgacaatgcctttaattccaggtttaagagcaa

\section{SCD-10572R}

10561 gccacaatgctatgt atgatgaacccettgggetgttctct tcccagtcatct ctgat

Figure 2. Positions of stearoyl-CoA desaturase $(S C D)$ primers. Bold type shows the $S C D$ gene fifth exon. The primers were designed by Medrano et al. (2003).

mentas International Inc., Burlington, Canada; Taq DNA polymerase 0.05 units $/ \mu \mathrm{L}, \mathrm{MgCl}_{2}, 4 \mathrm{~m} M$, and dNTP, $0.4 \mathrm{~m} M$ of each), $0.5 \mu \mathrm{L}$ of $10 \mathrm{pmol} / \mu \mathrm{L}$ primer forward, $0.5 \mu \mathrm{L}$ of $10 \mathrm{pmol} / \mu \mathrm{L}$ reverse primer, $250 \mathrm{ng}$ of DNA and $\mathrm{ddH}_{2} \mathrm{O}$ up to $25 \mu \mathrm{L}$. Among the several PCR products, the 725-bp fragment obtained using $S C D-9848 \mathrm{~F}$ and $S C D-10572 \mathrm{R}$ primers was retained for the genotyping (Figure 3 ).

\section{PCR-Single Strand Conformation Polymorphism Analysis}

The $S C D$ genotypes were assessed analyzing the DNA fragment containing the polymorphisms with an adapted single strand conformation polymorphism (SSCP) method (Ceriotti et al., 2004): $6 \mu \mathrm{L}$ of PCR product were added to $8 \mu \mathrm{L}$ of denaturing solution ( $0.025 \%$ of xylene-cyanol, $0.025 \%$ of bromophenol blue, and 0.02 $M$ EDTA in deionized formamide). After heat denaturation $\left(95^{\circ} \mathrm{C}\right.$ for $\left.8 \mathrm{~min}\right)$, samples were immediately chilled on ice and then run $\left(16 \mathrm{~h}, 280 \mathrm{~V}, 5^{\circ} \mathrm{C}\right)$ on $8 \%$ acrylamide:bis-acrylamide gels (37:1) with $1 \%$ glycerol in $0.5 \times$ Tris-borate-EDTA buffer. The SSCP method was preferred due to its capability to detect other possible modifications in the fragment analyzed.

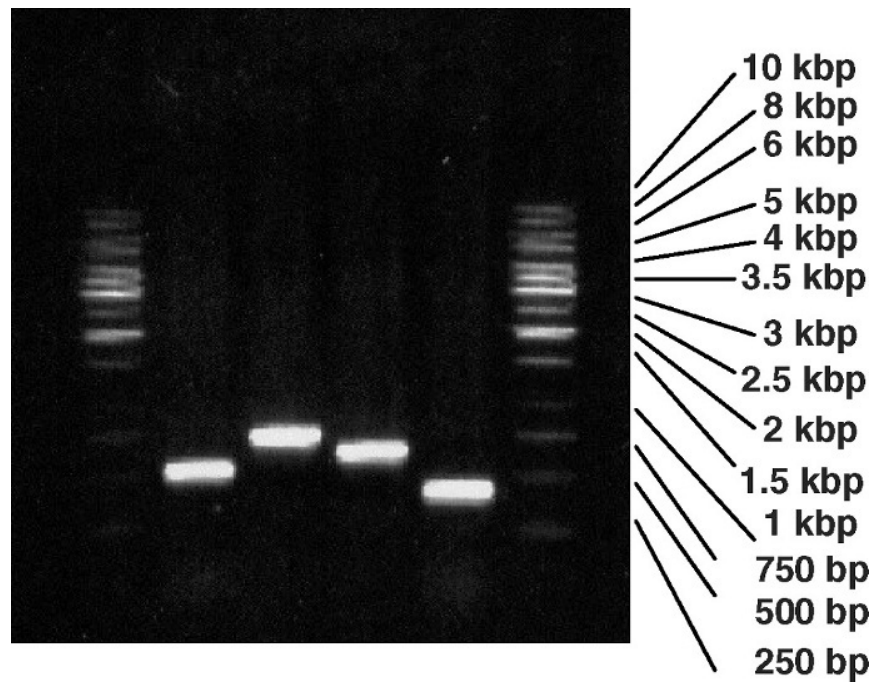

Figure 3. The PCR products: lane 1 and 6- GeneRuler $1 \mathrm{~kb}$ DNA ladder (Fermentas International Inc., Burlington, Canada); lane 2$S C D-9848 \mathrm{~F} / S C D-10355 \mathrm{R}$ product (508 bp); lane $3 S C D-9848 \mathrm{~F} / S C D$ $10572 \mathrm{R}$ product $(725 \mathrm{bp}$ ); lane $4 S C D-9961 \mathrm{~F} / S C D-10572 \mathrm{R}$ product (612 bp); lane $5 S C D-9961 \mathrm{~F} / S C D-10355 \mathrm{R}$ product (395 bp). 


\section{DNA Sequencing}

The DNA samples with different SSCP gel patterns were further sequenced by PRIMM Srl (Milan, Italy). One sample for every assumed genotype was randomly chosen. Primers used for sequencing were the same of the PCR-SSCP analysis. Nucleotide sequences were analyzed with Chromas 2.24 software (Technelysium Pty Ltd.).

\section{Milk Fat Analysis}

Individual milk samples were taken at the morning milking and stored at $-20^{\circ} \mathrm{C}$. One milk sample was taken per animal. Milk fat was extracted following the Rose-Gottlieb method (AOAC, 1990) modified by Secchiari et al. (2003). Two grams of milk were mixed with $0.4 \mathrm{~mL}$ of ammonia $25 \%, 1 \mathrm{~mL}$ of ethyl alcohol $95 \%$, and $5 \mathrm{~mL}$ of hexane, vortexed, and centrifuged at 1,600 $\times g$ and $4^{\circ} \mathrm{C}$. The upper layer was collected, and a second extraction with $1 \mathrm{~mL}$ of ethyl alcohol $95 \%$ and $5 \mathrm{~mL}$ of hexane was performed. A third extraction was made using $5 \mathrm{~mL}$ of hexane. The extracted fat was dried, weighed, and finally dissolved in hexane. Methyl esters of medium- and long-chain fatty acids were prepared by Christie's alkali catalyzed transmethylation procedure (1982) with nonadecanoic acid methyl ester (Sigma Chemical Co., St. Louis, MO) as the internal standard. Medium- and long-chain FA composition was determined by gas chromatography using a ThermoQuest (Milan, Italy) gas-chromatograph equipped with an FID and a high polar fused silica capillary column (Chrompack CP-Sil 88 Varian, Middelburg, the Netherlands; $100 \mathrm{~m} \times 0.25 \mathrm{~mm}$ i.d.; film thickness $0.20 \mu \mathrm{m}$ ). Helium was used as the carrier gas at a flow of $1 \mathrm{~mL} / \mathrm{min}$. The split ratio was 1:100. An aliquot of the sample was injected under the following GC conditions: the oven temperature was programmed at $120^{\circ} \mathrm{C}$ and held for 1 min, then increased to $180^{\circ} \mathrm{C}$ at a rate of $5^{\circ} \mathrm{C} / \mathrm{min}$, held for $18 \mathrm{~min}$, increased to $200^{\circ} \mathrm{C}$ at $2^{\circ} \mathrm{C} / \mathrm{min}$, held for 1 min, increased to $230^{\circ} \mathrm{C}$ at a rate of $2^{\circ} \mathrm{C} / \mathrm{min}$ and held for $19 \mathrm{~min}$. The injector temperature was set at $270^{\circ} \mathrm{C}$, whereas the detector temperature was set at $300^{\circ} \mathrm{C}$. Cis and trans C18:1 isomers were determined on a second aliquot of the same sample at $175^{\circ} \mathrm{C}$ (isothermal step) for 65 min using the same capillary column. Individual FA methyl esters were identified by comparing them to a standard mixture of 37 Component FAME Mix (Supelco, Bellefonte, PA). The standards PUFA-2, nonconjugated $\mathrm{C} 18: 2$ isomer mixture, individuals cis5,8,11,14,17 C20:5, cis-4,7,10,13,16,19 C22:6 (Supelco), cis-6,9,12 C18:3 and cis-9,12,15 C18:3 (Matreya Inc., Pleasant Gap, PA) were used to identify polyunsaturated FA. The identification of C18:1 isomers was based on commercial standard mixtures (Supelco) and pub- lished isomeric profiles (Wolff and Bayard, 1995). All the methods that use peak normalization and that express results as a relative percentage of the area of the analyzed peaks are subject to overestimation because of small peak areas not considered. To avoid this problem, a nonadecanoic acid as internal standard was used and all milk FA compositions were expressed as g/100 $\mathrm{g}$ of fat.

\section{Ratios of Milk Fatty Acids}

The extent of FA desaturation was determined by calculating the ratio of $c i s-9$ unsaturated to $c i s-9$ unsaturated + saturated for specific FA (Sol-Morales et al., 2000; Palmquist et al., 2004). The following ratios were calculated: cis-9 C14:1 to cis-9 C14:1 + C14:0 (C14:1/ C14); cis-9 C16:1 to cis-9 C16:1 + C16:0 (C16:1/C16); cis-9 C18:1 to cis-9 C18:1 + C18:0 (C18:1/C18); cis-9, trans-11 CLA to cis-9, trans-11 CLA + trans-11 C18:1 (CLA/trans-11 C18:1).

Moreover, a general index of desaturation (DI) was calculated (adapted from Malau-Aduli et al., 1997):

$$
\begin{aligned}
& \mathrm{DI}=100 \times[(c i s-9 \mathrm{C} 14: 1+c i s-9 \mathrm{C} 16: 1+c i s-9 \mathrm{C} 18: 1 \\
& \text { + cis-9, trans-11 CLA)/(cis-9 C14:1 + cis-9 C16:1 } \\
& \text { + cis-9 C18:1 + cis-9, trans-11 CLA+ C14:0 } \\
& \text { + C16:0 + C18:0 + trans-11 C18:1)]. }
\end{aligned}
$$

\section{Statistical Analysis}

Data were analyzed with the following mixed linear model (SAS, 1999):

$$
\begin{gathered}
\mathrm{y}_{\mathrm{jklmno}}=\mu+\mathrm{HERD}_{\mathrm{j}}+\mathrm{PARITY}_{\mathrm{k}}+\mathrm{DIM}_{\mathrm{l}} \\
+\mathrm{SEASON}_{\mathrm{m}}+\mathrm{SCD}_{\mathrm{n}}+\mathrm{SIRE}_{\mathrm{o}}+\varepsilon_{\mathrm{jklmno}}
\end{gathered}
$$

where $\mathrm{y}_{\mathrm{jklmno}}=$ dependent variable (milk fatty acids as $\mathrm{g} / 100 \mathrm{~g}$ of lipids, and FA ratios); $\mu=$ overall mean; HERD $_{j}=$ fixed effect of the jth herd (34); PARITY $_{k}=$ fixed effect of the kth parity (first, second, zthird); $\mathrm{DIM}_{1}=$ fixed effect of the lth days in milking interval $(<100,100$ to $200,>200) ;$ SEASON $_{m}=$ fixed effect of the mth calving season (winter, spring, summer, autumn); $S C D_{\mathrm{n}}=$ fixed effect of the nth $S C D$ genotype (AA, AV, VV); $\operatorname{SIRE}_{0}=$ random effect of the oth sire (21); and $\varepsilon_{\text {jklmno }}=$ random residual. Results on the $S C D$ genotype effects were presented as least square means \pm SE, and linear contrasts were tested between $\mathrm{AA}$ and $\mathrm{AV}$ genotypes and between $\mathrm{AV}$ and $\mathrm{VV}$ genotypes.

The average gene substitution effect for the $S C D$ locus on milk FA content was calculated according to 


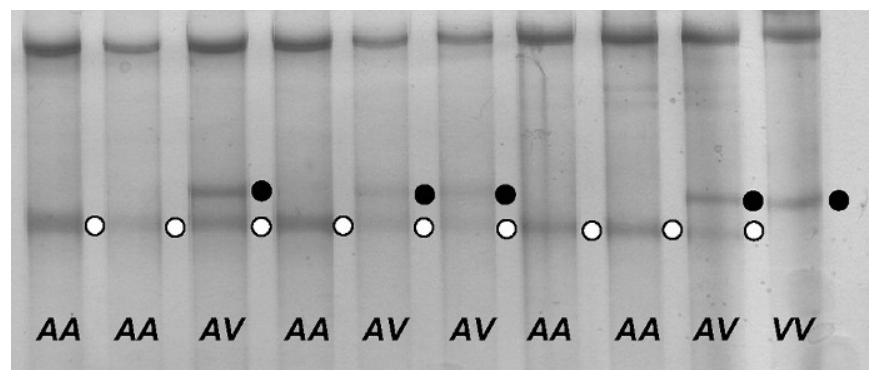

Figure 4. The PCR-single strand conformation polymorphism (SSCP) analysis for the fifth exon of the stearoyl-CoA desaturase $(S C D)$ gene polymorphism. The white and the black dots indicate the occurrence of $\mathrm{A}$ and $\mathrm{V}$, respectively.

Falconer and McKay (1996). The contribution of the $S C D$ locus to the variability of the traits considered was assessed by calculating the reduction of residual variance observed in the full model [1], in comparison with a reduced model that did not include the SCD genotype as fixed factor (Neter et al., 1996).

\section{RESULTS AND DISCUSSION}

Three different patterns were detected by the PCRSSCP analysis of the DNA fragment containing the polymorphism of the $S C D$ gene (Figure 4). The occurrence of a single lower or upper band was considered as evidence for a homozygous AA or VV, respectively, whereas both bands were regarded as an evidence for a heterozygous AV. This genotype assignment was confirmed by nucleotide sequencing. The different SSCP patterns corresponded to the third SNP (Figure 5): alleles $\mathrm{V}$ and $\mathrm{A}$ match the upper and the lower band, respectively.

Frequencies of $S C D$ genotypes observed in this sample of Italian Friesian cows are reported in Table 1. Genotypes were not in Hardy-Weinberg equilibrium ( $P$ $<0.05$ ); similar figures reported by Taniguchi et al. (2004) were ascribed to the sampling effect and to the selection pressure for other traits. Compared with the $\mathrm{V}$ allele, the higher frequency of the A allele $(0.57 \mathrm{vs}$. 0.43 , for alleles $\mathrm{A}$ and $\mathrm{V}$, respectively) is in agreement with results reported by the above-mentioned study ( 0.59 vs. 0.41 for alleles $\mathrm{A}$ and $\mathrm{V}$, respectively).

Stage of lactation affected significantly monounsaturated FA (MUFA), cis-9 C18:1, and cis-9 C14:1 and C14:0 contents. In the first $100 \mathrm{~d}$ of lactation, higher cis-9 C18:1 and lower C14:0 and cis-9 C14:1 contents were observed in comparison with later stages of lactation (Table 2), probably due to the mobilization of body fat reserves and to the inhibition of mammary lipogenic enzymes that occur in animals with negative energy

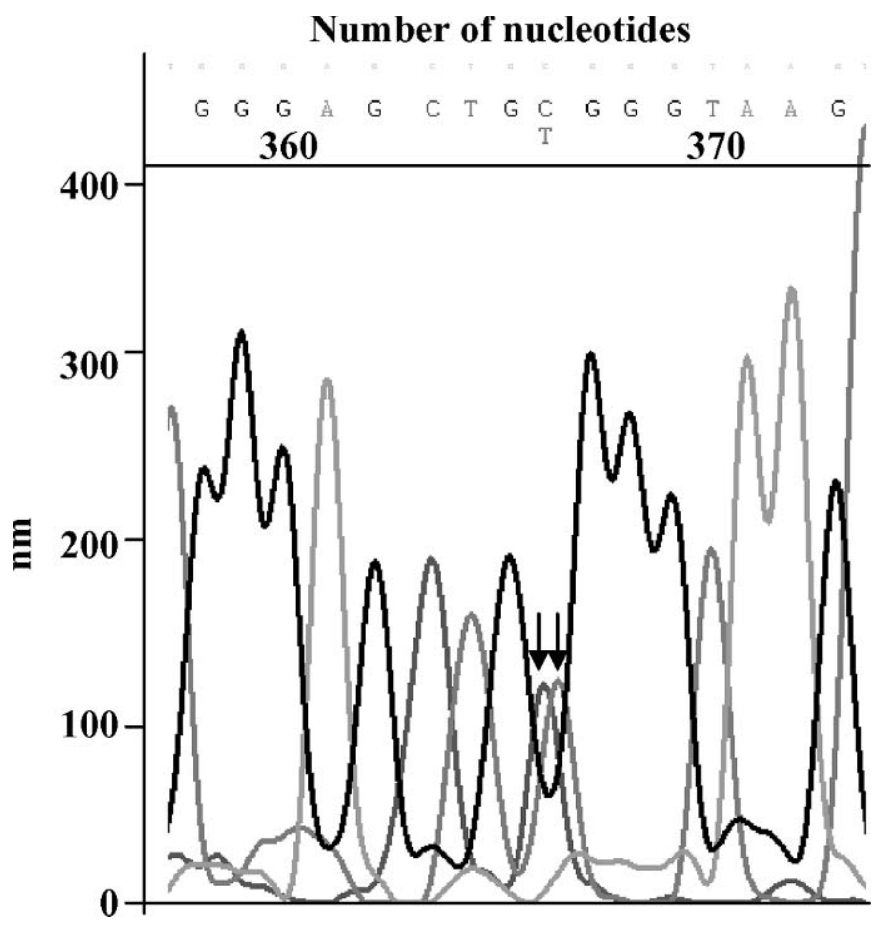

Figure 5. Nucleotide sequence results. The figure shows a region around the third single nucleotide polymorphism of a heterozygous sample, which is indicated by the 2 arrows.

balance (Kay et al., 2005). Parity and calving season did not affect significantly the variables considered.

The $S C D$ genotype affected significantly $(P \leq 0.01)$ cis9 C18:1, cis-9 C14:1, and total MUFA contents (Table 3). Particularly, the AA genotype was associated with 9.3, 37.9, and $11.7 \%$ more MUFA, cis-9 C14:1 and cis-9 C18:1, respectively, when compared with VV.

The $S C D$ average gene substitution effect was 0.83 , 0.93 , and $0.108 \%$ for MUFA, cis-9 C18:1, and cis-9 C14:1 content, respectively; the AA genotype showed 1.77, 1.93, and 0.22 higher MUFA, cis-9 C18:1, and cis-9 C14:1 contents than the genotype VV (Table 3), respectively. These results are in agreement with those reported by Taniguchi et al. (2004) on FA composition of carcass fat in cattle.

The relationship between $S C D$ polymorphism and milk cis-9, trans-11 CLA content is of particular inter-

Table 1. Distribution of stearoyl-CoA desaturase (SCD) genotypes in the 297 Italian Holsteins considered

\begin{tabular}{lcc}
\hline Genotype & $\begin{array}{c}\text { Absolute } \\
\text { frequencies (n) }\end{array}$ & $\begin{array}{c}\text { Relative } \\
\text { frequencies }(\%)\end{array}$ \\
\hline AA & 80 & 27 \\
AV & 179 & 60 \\
VV & 38 & 13 \\
Total & 297 & 100 \\
\hline
\end{tabular}


Table 2. Least squares means of selected measures of milk fatty acid content ( $\mathrm{g} / 100 \mathrm{~g}$ of total lipids) for different DIM intervals

\begin{tabular}{|c|c|c|c|c|c|c|}
\hline \multirow[b]{3}{*}{ Fatty acid } & \multicolumn{6}{|c|}{ DIM } \\
\hline & \multicolumn{2}{|c|}{$<100$} & \multicolumn{2}{|c|}{100 to 200} & \multicolumn{2}{|c|}{$>200$} \\
\hline & Mean & $\mathrm{SE}$ & Mean & $\mathrm{SE}$ & Mean & SE \\
\hline C14:0 & $8.04^{\mathrm{A}}$ & 0.24 & $9.33^{\mathrm{B}}$ & 0.18 & $9.38^{\mathrm{B}}$ & 0.28 \\
\hline $\mathrm{C} 16: 0$ & 23.70 & 0.56 & 25.09 & 0.63 & 24.02 & 0.44 \\
\hline C18:0 & 9.21 & 0.33 & 8.43 & 0.39 & 8.63 & 0.25 \\
\hline Trans-11 C18:1 & 0.73 & 0.03 & 0.75 & 0.05 & 0.80 & 0.02 \\
\hline Cis-9 C14:1 & $0.56^{\mathrm{A}}$ & 0.03 & $0.66^{\mathrm{AB}}$ & 0.04 & $0.79^{\mathrm{B}}$ & 0.02 \\
\hline Cis-9 C16:1 & 1.09 & 0.04 & 1.18 & 0.06 & 1.25 & 0.05 \\
\hline Cis-9 C18:1 & $18.99^{\mathrm{a}}$ & 0.44 & $17.88^{\mathrm{b}}$ & 0.54 & $17.86^{\mathrm{b}}$ & 0.35 \\
\hline Cis-9, trans-11 CLA ${ }^{1}$ & 0.37 & 0.03 & 0.34 & 0.04 & 0.40 & 0.03 \\
\hline MUFA $^{2}$ & $21.58^{\mathrm{a}}$ & 0.42 & $20.08^{\mathrm{ab}}$ & 0.48 & $19.33^{\mathrm{b}}$ & 0.40 \\
\hline
\end{tabular}

${ }^{\mathrm{A}, \mathrm{B}}$ Means within rows with different superscripts differ $(P<0.01)$.

${ }^{\mathrm{a}, \mathrm{b}}$ Means within rows with different superscripts differ $(P<0.05)$.

${ }^{1} \mathrm{CLA}=$ conjugated linoleic acid.

${ }^{2} \mathrm{MUFA}=$ monounsaturated fatty acids

est. Milk cis-9, trans-11 CLA content is characterized by individual variation (up to 8 -fold) that can be observed in cows fed the same diet (Bauman et al., 2001; Chilliard et al., 2001; White et al., 2001; Secchiari et al., 2003). Therefore, an important role of the genetic background of animals could be hypothesized. In our study, the AA genotype was associated with $12 \%$ more cis-9, trans-11 CLA when compared with VV; however, this difference did not reach the level of significance $(P=0.19)$, perhaps due to the small size of the sampled population.

In terms of explained variance, the contribution of $S C D$ genotype to MUFA variation in milk fat was quite low (5\%), in agreement with results reported for intramuscular fat in cattle (Taniguchi et al., 2004). Of the same magnitude are contributions of the $S C D$ genotype to cis-9 C18:1, and cis-9 C14:1 variation (4 and $7.7 \%$, respectively). These results suggest a reproducible and ubiquitous effect of the amino acid substitution. The contribution of $S C D$ genotype to the total variation of other FA profiles was nonsignificant and less than $1 \%$.

Sire effects accounted for 6,5 , and $8 \%$ of the total variance for content of cis-9 C18:1, and cis-9 C14:1, and MUFA, respectively. These values are indicative of an appreciable additive genetic effect on the variation in milk FA composition.

The analysis of desaturation activity indicators highlighted a significant effect of the $S C D$ polymorphism only on the C14:1/C14 ratio, with homozygous AA cows having the highest value (Table 4). The absence of a relationship between $S C D$ genotype and the other FA ratios could be ascribed to the wide range of factors influencing desaturation activity of the mammary gland such as differential uptake, use, and turnover of

Table 3. Least squares means of selected measures of milk fatty acid content ( $\mathrm{g} / 100 \mathrm{~g}$ of total lipids) for the 3 different stearoyl-CoA desaturase (SCD) genotypes

\begin{tabular}{|c|c|c|c|c|c|c|}
\hline \multirow[b]{3}{*}{ Fatty acid } & \multicolumn{6}{|c|}{$S C D$ genotype } \\
\hline & \multicolumn{2}{|c|}{ AA } & \multicolumn{2}{|c|}{ AV } & \multicolumn{2}{|c|}{ VV } \\
\hline & Mean & $\mathrm{SE}$ & Mean & $\mathrm{SE}$ & Mean & $\mathrm{SE}$ \\
\hline C14:0 & 8.49 & 0.25 & 8.85 & 0.17 & 8.88 & 0.31 \\
\hline $\mathrm{C} 16: 0$ & 23.92 & 0.60 & 24.12 & 0.41 & 23.17 & 0.72 \\
\hline C18:0 & 8.70 & 0.35 & 8.91 & 0.24 & 8.58 & 0.42 \\
\hline Trans-11 C18:1 & 0.76 & 0.03 & 0.77 & 0.02 & 0.74 & 0.03 \\
\hline Cis-9 C14:1 & $0.80^{\mathrm{A}}$ & 0.04 & $0.68^{\mathrm{B}}$ & 0.03 & $0.58^{\mathrm{B}}$ & 0.05 \\
\hline Cis-9 C16:1 & 1.17 & 0.05 & 1.16 & 0.04 & 1.10 & 0.06 \\
\hline Cis-9 C18:1 & $18.43^{\mathrm{A}}$ & 0.44 & $17.68^{\mathrm{B}}$ & 0.30 & $16.50^{\mathrm{B}}$ & 0.53 \\
\hline Cis-9, trans-11 CLA ${ }^{1}$ & 0.37 & 0.01 & 0.36 & 0.01 & 0.33 & 0.02 \\
\hline MUFA $^{2}$ & $20.72^{\mathrm{A}}$ & 0.47 & $20.30^{\mathrm{A}}$ & 0.32 & $18.95^{\mathrm{B}}$ & 0.57 \\
\hline
\end{tabular}

A,B Means within rows with different superscripts differ $(P<0.01)$.

${ }^{1} \mathrm{CLA}=$ conjugated linoleic acid.

${ }^{2} \mathrm{MUFA}=$ monounsaturated fatty acids 
Table 4. Least squares means of the fatty acid ratios for the 3 different stearoyl-CoA desaturase $(S C D)$ genotypes

\begin{tabular}{|c|c|c|c|c|c|c|}
\hline \multirow[b]{3}{*}{ Fatty acid } & \multicolumn{6}{|c|}{$S C D$ genotype } \\
\hline & \multicolumn{2}{|c|}{$\mathrm{AA}$} & \multicolumn{2}{|c|}{$\mathrm{AV}$} & \multicolumn{2}{|c|}{$\mathrm{VV}$} \\
\hline & Mean & $\mathrm{SE}$ & Mean & $\mathrm{SE}$ & Mean & $\mathrm{SE}$ \\
\hline $14: 1 / 14^{1}$ & $0.081^{\mathrm{A}}$ & 0.004 & $0.072^{\mathrm{B}}$ & 0.002 & $0.064^{\mathrm{B}}$ & 0.004 \\
\hline $16: 1 / 16^{2}$ & 0.047 & 0.002 & 0.048 & 0.001 & 0.044 & 0.002 \\
\hline $18: 1 / 18^{3}$ & 0.676 & 0.008 & 0.668 & 0.006 & 0.658 & 0.011 \\
\hline $\mathrm{CLA} /$ trans-11 C18: $1^{4}$ & 0.329 & 0.007 & 0.321 & 0.006 & 0.314 & 0.009 \\
\hline Desaturation index $(\mathrm{DI})^{5}$ & 0.331 & 0.007 & 0.321 & 0.005 & 0.311 & 0.009 \\
\hline
\end{tabular}

${ }^{\mathrm{A}, \mathrm{B}}$ Means within rows with different superscripts differ $(P<0.01)$.

${ }^{1} 14: 1 / 14=c i s-9$ C14:1/C14:0 + cis-9 C14:1.

${ }^{2} 16: 1 / 16=$ cis-9 C16:1/C16:0 + cis-9 C16:1.

${ }^{3} 18: 1 / 18=c i s-9$ C18:1/C18:0 + cis-9 C18:1.

${ }^{4} \mathrm{CLA} /$ trans-11 C18:1 = cis-9, trans-11 C18:2/trans-11 C18:1 + cis-9, trans-11 C18:2

${ }^{5} \mathrm{DI}=(c i s-9 \mathrm{C} 14: 1+c i s-9 \mathrm{C} 16: 1+c i s-9 \mathrm{C} 18: 1+c i s-9$, trans-11 C18:2) $/(\mathrm{C} 14: 0+c i s-9 \mathrm{C} 14: 1+\mathrm{C} 16: 0+c i s-$ 9 C16:1 + cis-9 C18:1 + C18:0 + trans-11 C18:1 + cis-9, trans-11 C18:2).

the different FA (Bernard et al., 2006). On the other hand, the $\mathrm{C} 14: 1 / \mathrm{C} 14$ ratio has been suggested as the best indicator for the SCD activity (Corl et al., 2001; Lock and Garnsworthy, 2003): C14:0 in milk fat derives almost exclusively from de novo synthesis in the mammary gland, and therefore, almost all the cis-9 C14:1 is likely to be synthesized by SCD (Bernard et al., 2006).

\section{CONCLUSIONS}

In the present study, a putative relationship between the genotype at the $S C D$ locus and the content of some milk FA in Italian Holsteins was found. In particular, associations of $S C D$ genotype with MUFA content and the $\mathrm{C} 14: 1 / \mathrm{C} 14$ ratio, an indicator of mammary desaturase activity, were indicated. Although the amount of MUFA variation explained by $S C D$ genotype was low, $S C D$ genotype may have a role in marker assisted selection programs aimed at improving the nutritional quality of milk. The absence of significant relationships between $S C D$ polymorphism and milk cis-9, trans-11 CLA isomer content should be carefully considered. Reasons for the relevant individual variability of this trait are not fully understood, and further studies on mechanisms influencing the availability of cis-9, trans-11 CLA (or its precursors) from the rumen, on $S C D$ gene expression regulation, and on differences in downstream factors that would affect interaction between enzyme and substrate (e.g., phosphorylation) are required (Bauman et al., 2003).

\section{ACKNOWLEDGMENTS}

Research supported by the Italian Ministero dell'Università e della Ricerca Scientifica (COFIN 2003). The authors acknowledge Adrian Wallwork (University of Pisa, Italy) for his critical reading of the manuscript.

\section{REFERENCES}

AOAC. 1990. Official Methods of Analysis. Vol. I. 15th ed. AOAC, Arlington, VA.

Bauman, D. E., B. A. Corl, L. H. Baumgard, and J. M. Griinari. 2001. Conjugated Linoleic Acid (CLA) and the dairy cow. Pages 221-250 in Recent Advances in Animal Nutrition 2001. P. C. Garnsworthy, and J. Wiseman, ed. Nottingham Univ. Press, Nottingham, UK.

Bauman, D. E., B. A. Corl, and D. G. Peterson. 2003. The biology of conjugated linoleic acids in ruminants. Pages 146-173 in Advances in Conjugated Linoleic Acid Research, Vol. 2. J. L. Sébédio, W. W. Christie, and R. Adlof, ed. AOCS Press, Champaign, IL.

Bauman, D. E., I. H. Mather, R. J. Wall, and A. L. Lock. 2006. Major advances associated with the biosynthesis of milk. J. Dairy Sci. 89:1235-1243.

Bernard, L., C. Leroux, and Y. Chilliard. 2006. Characterization and nutritional regulation of the main genes in the lactating mammary gland. Pages 295-326 in Ruminant Physiology. K. Sejrsen, T. Hvelplund, and M. O. Nielsen, ed. Wageningen Academic Publisher, Wageningen, the Netherlands.

Ceriotti, G., S. Chessa, P. Bolla, E. Budelli, L. Bianchi, E. Duranti, and A. Caroli. 2004. Single nucleotide polymorphism in the ovine casein genes detected by polymerase chain reaction single strand conformation polymorphism. J. Dairy Sci. 87:2606-2613.

Chilliard, Y., A. Ferlay, and M. Doreau. 2001. Effect of different type of forages, animal fat or marine oils in cow's diet on milk fat secretion and composition, especially conjugated linoleic acid (CLA) and polyunsaturated fatty acids. Livest. Prod. Sci. 70:31-48.

Christie, W. W. 1982. A simple procedure of rapid transmethylation of glycerolipids and cholesteryl esters. J. Lipid Res. 23:1072-1075.

Corl, B. A., L. H. Baumgard, D. A. Dwyer, J. M. Griinari, B. S. Phillips, and D. E. Bauman. 2001. The role of $\Delta^{9}$-desaturase in the production of cis-9, trans-11 CLA. J. Nutr. Biochem. 12:622-630.

Falconer, D. S., and T. F. C. McKay. 1996. Introduction to Quantitative Genetics. 4th ed. Longmans Green, Harlow, UK.

Jenkins, T. C., and M. A. McGuire. 2006. Major advances in nutrition: Impact on milk composition. J. Dairy Sci. 89:1302-1310.

Kay, K., W. J. Weber, C. E. Moore, D. E. Bauman, L. B. Hansen, H. Chester-Jones, B. A. Crooker, and L. H. Baumgard. 2005. Effects of week of lactation and genetic selection for milk yield on milk 
fatty acids composition in Holstein cows. J. Dairy Sci. 88:38863893.

Lock, A. L., and P. C. Garnsworthy. 2003. Seasonal variation in milk conjugated linoleic acid and $\Delta^{9}$ desaturase activity in dairy cows. Livest. Prod. Sci. 79:47-59.

Malau-Aduli, A. E. O., B. D. Siebert, C. D. K. Bottema, and W. S. Pitchford. 1997. A comparison of the fatty acids composition of triacylglycerols in adipose tissue from Limousin and Jersey cattle. Aust. J. Agric. Res. 48:715-722.

Medrano, J. F., A. D. Islas-Trejo, A. M. Johnson, and E. J. De Peters. 2003. Genomic structure and expression of the bovine stearoylCoA desaturase gene. GenBank, accession number AY241933. http://www.ncbi.nlm.nih.gov/Genbank/index.html Accessed Sept. 2006.

Medrano, J. F., A. Johnson, E. J. DePeters, and A. Islas. 1999. Genetic modification of the composition of milk fat: Identification of polymorphisms within the bovine stearoyl-CoA-desaturase gene. J. Dairy Sci. 82(Suppl. 1):71. (Abstr.)

Neter, J., M. H. Kutner, C. J. Nachtsheim, and W. Wasserman. 1996. Applied Linear Statistical Models. McGraw-Hill Co. Inc., Chicago, IL.

Ntambi, J. M. 1999. Regulation of stearoyl-CoA desaturase by polyunsaturated fatty acids and cholesterol. J. Lipid Res. 40:1549-1558.

Ntambi, J. M., and M. Miyazaki. 2004. Regulation of stearoyl-CoA desaturases and role in metabolism. Prog. Lipid Res. 43:91-104.

Palmquist, D. L., A. D. Beaulieu, and D. M. Barbano. 1993. Feed and animal factors influencing milk fat composition. J. Dairy Sci. 76:1753-1771.

Palmquist, D. L., N. St-Pierre, and K. E. McClure. 2004. Tissue fatty acid profiles can be used to quantify endogenous rumenic acid synthesis in lambs. J. Nutr. 134:2407-2414.
Pariza, M. W. 1999. The biological activities of conjugated linoleic acid. Pages 12-20 in Advances in Conjugated Linoleic Acid Research, Vol. I. M. P. Yurawecz, M. M. Mossoba, J. K. G. Kramer, M. W. Pariza, and G. J. Nelson, ed. AOCS Press, Champaign, IL.

SAS User's Guide. 1999. Statistics, Version 8.0 Edition. SAS Inst. Inc., Cary, NC.

Secchiari, P., M. Antongiovanni, M. Mele, A. Serra, A. Buccioni, G. Ferruzzi, F. Paoletti, and F. Petacchi. 2003. Effect of kind of dietary fat on quality of milk fat from Italian Friesian cows. Livest. Prod. Sci. 83:43-52.

Sol-Morales, M., D. L. Palmquist, and W. P. Weiss. 2000. Effect of fat source and copper on unsaturation of blood and milk triacylglycerol fatty acids in Holstein and Jersey cows. J. Dairy Sci. 83:2105-2111.

Soyeurt, H., P. Dardenne, A. Gillon, C. Crocquet, S. Vanderick, P. Mayeres, C. Bertozzi, and N. Gengler. 2006. Variation in fatty acid contents of milk and fat within and across breeds. J. Dairy Sci. 89:4858-4865.

Taniguchi, M., T. Utsugi, K. Oyama, H. Mannen, M. Kobayashi, Y. Tanabe, A. Ogino, and S. Tsuji. 2004. Genotype of stearoyl-CoA desaturase is associated with fatty acids composition in Japanese Black cattle. Mamm. Genome 14:142-148.

White, S. L., J. A. Bertrand, M. R. Wade, S. P. Washburn, J. T. Jr. Green, and T. C. Jenkins. 2001. Comparison of fatty acid content of milk from Jersey and Holstein cows consuming pasture or total mixed ration. J. Dairy Sci. 84:2295-2301.

Wolff, R. L., and C. C. Bayard. 1995. Improvement in the resolution of individual trans 18-1 isomers by capillary gas liquid chromatography: Use of a 100 m CP Sil-88 column. J. AOCS 72:1197-1201. 